\title{
Lumen
}

Selected Proceedings from the Canadian Society for Eighteenth-Century Studies

\section{Srinivas Aravamudan's Enlightenment Orientalism: Resisting the Rise of the Novel: A Roundtable Discussion}

\section{Katherine Binhammer, Eugenia Zuroski Jenkins, Daniel O’Quinn, Mary Helen McMurran et Srinivas Aravamudan}

Volume 33, 2014

URI : https://id.erudit.org/iderudit/1026562ar

DOI : https://doi.org/10.7202/1026562ar

Aller au sommaire du numéro

Éditeur(s)

Canadian Society for Eighteenth-Century Studies / Société canadienne d'étude du dix-huitième siècle

ISSN

1209-3696 (imprimé)

1927-8284 (numérique)

Découvrir la revue

Citer cet article

Binhammer, K., Zuroski Jenkins, E., O’Quinn, D., McMurran, M. H. \& Aravamudan, S. (2014). Srinivas Aravamudan's Enlightenment Orientalism: Resisting the Rise of the Novel: A Roundtable Discussion. Lumen, 33, 1-26. https://doi.org/10.7202/1026562ar 


\title{
Srinivas Aravamudan's Enlightenment Orientalism: Resisting the Rise of the Novel: A Roundtable Discussion ${ }^{1}$
}

\author{
I - Katherine Binhammer \\ University of Alberta
}

Enlightenment Orientalism has two main goals: first, to delineate an experimental and cosmopolitan eighteenth-century Orientalism that has been hidden from critical history by its nineteenth-century imperialist counterpart; and second, to contest the dominant national realist narrative of the novel's rise in Britain by repositioning fantasy and satire-the most popular modes for Oriental fictions-as central to the story of the novel. My response below will attempt to capture the diverse and fresh insights that the frame 'Enlightenment Orientalism' makes visible and will also consider the tensions that emerge when the first goal of rethinking Orientalism is placed beside the second of critiquing the national realist novel.

Aravamudan coins the phrase "Enlightenment Orientalism" to foreground the historicism of its oxymoronic signification. The title invites us to query how there could be anything 'enlightened' about 'Orientalism,' since the term entered twentieth-century scholarly parlance as signifying a hegemonic imperialist movement. Aravamudan answers the query by challenging the assumption that Orientalism,

1. The following reproduces a roundtable discussion which took place at "The Cultures of Global Exchange" on Srinivas Aravamudan's Enlightenment Orientalism: Resisting the Rise of the Novel (Chicago: University of Chicago, 2011). All references to the book will cited parenthetically. Roundtable participants were (in the order of their response below): Katherine Binhammer, Eugenia Zuroski Jenkins, Daniel O’Quinn, Mary Helen McMurran, Srinivas Aravamudan. 
understood as Europe's engagement with the East, was always already imperialist in intent and form and demonstrating that the eighteenth century's interest in the East is defined by its curiosity about, and experimentation with, literature and philosophy from China, India, and the Levant. Enlightenment Orientalism has been a victim of, what Aravamudan calls, "Saidian Orientalism," referring to Edward Said's masterful depiction of a colonizing nineteenth-century discourse. Instead of reading eighteenth-century European encounters with the East as part of a progressive history that inevitably ends in our postcolonial moment, the book traces an alternative strain of Orientalism, rising out of Enlightenment forms of inquiry. Enlightenment Orientalism, then, is the epistemologically inventive, open-ended, cosmopolitan sister to its hegemonic, imperialist, Victorian brother.

In reanimating an eighteenth-century discourse in the twenty-first century, one blinded to us in the intervening centuries by a nineteenthcentury Orientalism, Aravamudan is part of a larger movement to reposition the Enlightenment outside a Horkheimer and Adorno frame in which the origin of modernity's tyranny is located in the eighteenth century. Enlightenment Orientalism begins from a different perspective, refusing to read the period through the glasses of hindsight and reading it instead for alternative historical teleologies than the one that became dominant. I call this movement, after Giovanni Arrighi’s work on historical cycles, "the long twentieth century. ${ }^{2}$ By working with a historical methodology that reads our contemporary global moment as echoing the cycle of accumulation in the eighteenth century, the long twentieth-century scholar thinks about how the present moment has more in common with the eighteenth century than anything in between. Ian Baucom's Specters of the Atlantic exemplifies this scholarship; Baucom argues that "as [Walter] Benjamin's nineteenth century repeats or inherits the seventeenth century by intensifying it, so the long twentieth century under discussion here extends or inherits the eighteenth by intensifying it." 3 In reanimating an Enlightenment Orientalism, Aravamudan does for the East what Baucom did for the Atlantic; he makes readable and knowable an eighteenth-century

2. Giovanni Arrighi, The Long Twentieth Century: Money, Power, and the Origins of Our Times (London: Verso, 1994).

3. Ian Baucom, Specters of the Atlantic: Finance Capital, Slavery, and the Philosophy of History (Durham: Duke University Press, 2005), p. 22. 
speculative philosophical Orientalism that was unknowable until the twenty-first century.

What constitutes this knowledge? What alternative modes of thinking about the East does Enlightenment Orientalism unearth? First and foremost, it establishes the centrality of the East to the Enlightenment philosophical project of skeptical investigation through comparative analysis. What Aravamudan calls the genre of "pseudoethnography" - which includes texts such as The Turkish Spy and Lettres Persanes and is defined by its transcultural thought-experiments comparing West with East - unleashes a radically destabilized understanding of the European subject, not one whose claim to world dominance is presupposed. When the universalist humanist project is viewed from the perspective of these skeptical texts, Europe-in particular, France and Britain - is not seen as encountering the East from a position of dominance but from an "experimental, prospective, and antifoundationalist" point of view (4). Whereas a Saidian Orientalism understands space as territory, Enlightenment Orientalism is about a utopic universal in which space is transversal. A 'long twentieth century' literary history that emphasizes fiction's cosmopolitan roots makes readable many texts that were largely unreadable to twentieth-century scholarship: cosmological fantasies like Fontenelle's Entretiens sur la Pluralité des Mondes; philosophical adaptations of the Fables of Pilpay; and libertine satires such as Crébillon's Le Sopha.

Fantasy as a central mode of prose fiction is one of the most persuasive new objects that Enlightenment Orientalism's long twentieth century brings into view. As the subtitle underscores, "resisting the rise of the novel" is the book's major polemic: stories of the novel's rise from Ian Watt on, even the most sophisticated recent ones that are open to difference, presume a certain stability to the object 'novel' based in realism and the form's national origin. Aravamudan does not offer a counter origin story but dislodges the dominant story by investigating the plethora of modes of prose fiction-philosophical, experimental, satiric, fantastical, didactic, etc.-that do not conform to the national realist novel. Insightfully, he queries the collapse of realism with psychological interiority as if other narrative points of view preclude interiorized voices. "The novel," he writes, "is not the sole hero of the creation of a singular modernity through the fabrication of psychological interiority; the former can be fashioned in multiple ways by 
various techniques of immersiveness that do not have to be normatively mimetic or based on a correspondence theory of truth" (205).

In not proposing a counter-narrative of the novel's origins, in "resisting the rise of the novel," Enlightenment Orientalism convinces by demonstrating the 'always already' national and generic messiness of the domestic realist text, for example, the way that Clarissa is indebted to French fictional Orientalism in Lovelace's self-fashioning as an Oriental sultan and in Clarissa insistence that he is a despot. It is not just that Aravamudan opens up 'the canon' of the novel to include previously marginalized texts, but that he shows how novels traditionally cited to prove that realism and Britishness birthed the novel, in fact, incorporate Orientalist techniques and motifs. "Such a reading strategy," he writes, "aims to unsettle the neat distinctions that novel criticism, nationalism, and cultural theory have reified. Domesticity, the family, and Christianity are not just autochthonous structures but are reproduced in every epoch in dialogue with exoticism, estrangement, and immorality" (176). The 'unsettling' is taken further in the discussion of fantasy when he argues that far from being a counter to realism, fantasy can be, as he calls it, "reality oriented" (152). Fantasy is deployed within Oriental fiction not to mask reality but to demystify it, thus revealing a great, more universal truth. "What," he asks, "if a theory of realism were founded on the pursuit of dissimilitudes rather than the recognition of sameness?" (21). This chiasmatic thinkingthat realism can be inflected with fantasy just as fantasy can have a realistic impetus-leaves the novel's origins in a muddy unruly antifoundationalism and broadens our understanding of the sheer radicalness of eighteenth-century experiments in prose.

Enlightenment Orientalism is based on the rejection of a historical teleology in which the nineteenth-century nation state is retrospectively read back into the eighteenth century to construct a national realist fictional tradition. "[T]he mechanisms of national realism anchor a particular historicism," Aravamudan writes and "[a]lternative possible worlds ended up being slotted into secondary positions as figurations of the "merely' fantastic" (239). Given this loaded critical past, should we abandon all reference to the category of realist fiction? While one of Aravamudan's most persuasive moves is to show how many texts traditionally considered stable national realist novels are 
not purely so (for example, Robinson Crusoe), the argument often posits The National Realist novel as a straw man against which Oriental fictions emerge as bountifully more rich, less ideological, and wonderfully indeterminate. In other words, the two goals of the book-Enlightenment Orientalism and resisting the rise of the novel-propose different interpretations of domestic fiction. I am convinced that Frances Sheridan's History of Nourjahad is a rich and complex text "that makes a mockery of the division of supposedly realist and fantastic genres" (237); I am not convinced that The History of Sir Sidney Biddulph is not equally as rich and complex. Aravamudan does not mention Sidney Biddulph and he is not arguing that realist novels are monolithic, offering, instead, the far more satisfying polemic that domestic realist fiction is always already a miscegenated genre, imbued with an Eastern heritage. But in order to claim that Enlightenment Orientalism is not Saidian Orientalism, he has to set it up against a national realist novel that, in another register, he has shown does not exist. The straw man argument is strongest when it turns out that the national domestic realist novel is responsible for forcing the cure on Lennox's Arabella and causes Catherine Morland to be disabused of her enabling gothic delusions. In these examples, he argues, "we see a disciplinary scene of correct reading, whereby national realist authority expels fable, romance, oriental tale, and other fictional forms while reasserting approved generic protocols" (140). Is the national realist novel a stable object produced by eighteenth-century critics that necessitates Arabella's cure and colludes with Saidian Orientalism? Or is it only retrospectively created as an object by literary historians as evidence for the 'rise of Modernity' thesis? Can it be both?

In closing, I turn from reading the past to questioning why we are reading this past now; that is to say, when and where are we looking from? Why Enlightenment Orientalism now? There is what we might call a 'New Orientalisms' in eighteenth-century studies. A recent special issue of Eighteenth-Century Fiction on "Exoticism and Cosmopolitanism" (edited by Eugenia Zuroski Jenkins, a member of our panel) reviews no less than eight new books in the field, all published since the first and important works of the New Orientalisms by Ros Ballaster (Fabulous Orients 2005) and Robert Markley (The Far 
East and the English Imagination 2006). ${ }^{4}$ The sheer number of critical texts makes one wonder why we are now able to see this eighteenth century? What are the historical conditions of our present that allow us to hold up a looking glass into the past? Oliver Goldsmith's Citizen of the World is one of the texts that has now become readable; in it, the Chinese traveler and letter-writer Lien Chi Altangi describes a magical looking glass from Lao that mirrors back not a person's physical surface but their interior truths (which, in the case of the British fashionable world that Goldsmith satirizes, are truths of hypocrisy, vanity and envy). Is there a looking glass that would mirror back for us our own historicity? If we could hold up a mirror to our current scholarly moment and see how the twentieth-first century shapes our eighteenth century, what would it tell us? Aravamudan shows us how the view of the eighteenth century from the perspective of twentieth-century scholars was coloured by the progress of modernity in the nineteenth century. What is colouring our vision now? Why now are we persuaded that there was a wonderful, fabulous, experimental Enlightenment Orientalism?

\section{II - Eugenia Zuroski JENKINS \\ McMaster University}

Reading Enlightenment Orientalism was, for me, a thrilling and satisfying experience that stimulated a host of interesting anxieties. I felt a deep affinity with the book's argument and insights, perhaps because Aravamudan's work has been so influential on my own. (I read Tropicopolitans 5 as I was formulating my dissertation topic in 1999, and, in that same semester, heard the talk at Brown University on Eliza Haywood that Enlightenment Orientalism acknowledges as one of its starting points. I was also fortunate, as an assistant at Novel: A Forum on Fiction in those same days, to help prepare the article that came out

4. "Exoticism and Cosmopolitanism," Eighteenth-Century Fiction, 25.1 (Fall 2012); Ros Ballaster, Fabulous Orients: Fictions of the East in England, 1662-1785 (Oxford: Oxford University Press, 2005); and Robert Markley, The Far East and the English Imagination (Cambridge: Cambridge University Press, 2006).

5. Srinivas Aravamudan, Tropicopolitans: Colonialism and Agency, 1688-1804 (Durham, N.C.: Duke University Press, 1999). 
of that talk for publication-material that reappears in Chapter 5 of the book. $\left.{ }^{6}\right)$ Reading the just-published Enlightenment Orientalism while completing the last round of revisions on my own book, I was seized by the feeling that this book was saying all kinds of things that I had been trying to think, which rendered all of us-me, Aravamudan's book, my own work-uncanny in ways that are probably valuable but not exactly reassuring. Moreover, when one reads a book that one agrees with so much, it is impossible not to wonder whether you are reading the book at all, hearing what it is actually saying, and not prematurely incorporating it into your own epistemological edifice.

These dynamics of deeply intertwined modes of recognition and alienation in the act of reading are, of course, one of the book's primary concerns. Enlightenment Orientalism delivers on the promise of Ros Ballaster's play on the "narrative moves" of oriental tales, ${ }^{7}$ directing our attention to a different set of movements than those privileged by the imagined upward progress of the "rising" novel. These movementsperformed alike by narrative, the texts that contain them, and the subjects who read them-are horizontal and multidirectional: we are called to witness transport, transformation, translation, transcoding, transmission, and so on. Ultimately, the book impresses us with the power of what we might call transfictions to transfix us-in other words, to engender states of being that remain in imaginary motion across the boundaries of singular selfhood.

This argument is advanced in resistance to the still predominant paradigm of the realist novel as the fictional expression of modern, nationalist Western selfhood, and it is a powerful call to rethink the epistemology of fiction in the context of cosmopolitanism. Through the dual critical frameworks of Saidian Orientalism and the nationalist rise of the novel, we have become accustomed to measuring works of fiction against their own fictionality, emphasizing their deviations from historically based norms. The historical inaccuracies of fiction are read as either a flimsy commitment to Western truth-telling-a lack of cultural seriousness - or a motivated effort to distort the world "as it is" to tell ideological tales about Western supremacy. What if instead,

6. Srinivas Aravamudan, "In the Wake of the Novel: The Oriental Tale as National Allegory," Novel: A Forum on Fiction 33, no. 1 (Autumn 1999): 5-31.

7. Ros Ballaster, Fabulous Orients: Fictions of the East in England, 1662-1785 (New York: Oxford University Press, 2005), 1-24. 
this book asks, we were to attend to the fictionality of fiction in a different way, reading fiction as a discourse of and about the world without dismissing or disavowing its fictiveness as a viable way of understanding the world? What is at stake here is a radical, literary definition of truth-telling. We are asked to consider not only what types of voices are authorized to contribute to truthful narratives, but what generic registers are authorized to pursue truth at all. Or, to put it another way, in what ways do fiction's untruths generate enlightenment?

These questions address the mandate of literary cultural studies to "historicize" our reading. While "historicized" reading has undoubtedly generated important work, there are also plenty of reasons to unmoor our standard of meaningful insight from the genre of historical narrative. By merely supplementing histories with alternative histories, we stake out a cultural field in which diverse voices compete for the authority to tell the one story about the world that counts. It is precisely this model of "differing accounts" that generates the maddening public discourse on "balanced" reporting and its investment in "both sides of the story," where dividing a singular narrative in two gives the appearance of diversifying it. We are then invited to assume that the truest truth must be located on some imaginary point equidistant from the competing claims, that is, in the so-called "middle," where differing accounts are resolved into a comforting sameness. Learning to listen to the heteroglossic voice of fiction would be a departure from the cultivation of an apparent diversity that permits the possibility only of multiple versions of the same story. Enlightenment Orientalism advances a theory of reading based less on the identifications encouraged by verisimilar realism than on the disorientations provoked by oriental tales.

How, then, does such a theory of reading compel a rethinking of subjectivity? One of the questions that sticks with me in the wake of this book is whether we must leave behind the idea of subjective interiority in order to pursue fiction's transcultural movements. No doubt this model of selfhood has been wrangled by the realist novel to be the seat of an individuated, self-same form of personal agency, but might it be recruited instead to help us rethink the modern subject as the effect of lateral movements? I am thinking in particular of the subject's epistemological traffic with its ostensible others-namely objects, including but not limited to oriental fictional texts. Might subjective 
interiority itself be theorized as a cosmopolitan space, facilitating subject-object relations that are a form of exchange rather than dialectical struggle or, as described in the book's discussion of it-narratives, a set of "parallel and formally equivalent [but] ultimately irreconcilable" narratives (198)? The chapter on multiple worlds and talking animals, for example, called to my mind the contemporaneous market for chinoiserie and other decorative objects depicting just such imaginary landscapes and figures. Might we read such objects as forms of Enlightenment Orientalist fiction, which install experimental worlds materially in English homes where they are simultaneously imaginary and real? To do so, it seems to me, offers a way of rethinking the role of foreign objects in the constitution of subjectivity beyond versions of "fetishism," and of understanding the Enlightenment's experiments in "taste" without presuming that they were always either a form of epistemological imperialism over the object world, or a justification for consumer desires that compromised the integrity of subjects who indulged them. Could transcultural reading help us reconsider not only the hermeneutics but also the aesthetics of everyday life? If English domestic space might be rethought as a site of fictional experimentation that sustains rather than eradicates the forms of difference introduced through consumerism, then might the "depths" of the reading subject be similarly retheorized as "interpersonal" or "public-personal" space that facilitates other kinds of movement than those typically attributed to modern, Western subjectivity? How is the "transfixed" subject "moved," in other words, to other modes of experience and understanding? Where do the encounters take place that move one to other enlightenments?

\section{III - DANIEL O’QUINN University of Guelph}

I come into this discussion as someone who has little stake in Enlightenment Orientalism's resistance to the rise of the novel; I basically agree with its Fontenellian critique of generic exceptionalism via the proliferation of worlding fictions. But I want to explore the subtle tactics through which this book provides a genealogy of orientalism's effects. My focus here may be eccentric - I tend to work on the theatre and 
the press-but these other media were a vital part of the emergence of a global representational economy. This is a period when you might well read accounts of the health of the Sultan of Morocco, catch up on the latest news from America and check the shipping news from India in the Public Advertiser at breakfast, read a couple of chapters of Hawkesworth's account of Cook's voyage before tea, ponder some new inventions in the Gentleman's Magazine and then head off to see Dibdin's The Seraglio at Covent Garden. A whole day with nary a novel in sight. By adding travel narratives, the ephemeral daily press and the nightly experience of the theatre into the mix I want to point to another way in which the pluralization of the archive could displace the selffulfilling teleology of "novelism."

In his recent review, Zak Sitter argues that "because only texts that eschew the claims of factual reference are considered, Aravamudan's Enlightenment Orientalism tends to preserve its innocence of the entanglements of power and knowledge." ${ }^{8}$ This is perhaps most forcefully seen in the careful separation of Montesquieu's Lettres Persanes from the climatological racism of LEsprit du lois and even more significantly from Baron De Tott's Memoirs, whose application of Montesquieu's climatological account of Eastern despotism had an extraordinary effect on the historiography surrounding the breakup of the Ottoman empire. But Sitter does not acknowledge that the structure of each of the book's chapters is genealogical-i.e. by following particular genres across time, Aravamudan subtly shows how the thought experiments of pseudoethnography and transcultural allegory or those coded into animal tales became progressively tamed by national fantasy. I want to play out a similar genealogical trajectory in relation to a play that mobilizes many of the book's favourite topoi, thus putting the argument about the novel aside for a moment, in order to better see how enlightenment critique is blunted by the force of imperial and national history.

Zara, Aaron Hill's immensely successful adaptation of Voltaire's Zaïre, provides a valuable case study for exploring the function of Islam on the London stage during the reign of George II. First performed at

8. Zak Sitter, "Review: Enlightenment Orientalism: Resisting the Rise of the Novel, and The Postcolonial Enlightenment: Eighteenth-Century Colonialism and Postcolonial Theory," Eighteenth-Century Fiction, 25.1 (Fall 2012): 250-55. 
Drury Lane in 1736 to great acclaim and considerable receipts, it was later altered by Garrick in 1754 and became a staple of the repertoire.? The title role is synonymous with the career of Susannah Cibber: it secured her status as a tragic actress when she debuted the part in 1736 and she played Zara for her entire life, quite literally owning the role under Garrick's management. In the play's later manifestation, Garrick turned the aged French patriarch Lusignan into one of his signature roles. The play has received very little critical attention in spite of the fact that it became a mainstay not only for Cibber and Garrick, but also for Elizabeth Younge. ${ }^{10}$ Significantly, the play was one of the few failures in Sarah Siddons foray into tragedy in the 178 os and that failure is telling, because as we will see the play was becoming less and less emotionally coherent. Because Zara is regularly performed over a fifty-year time frame we can demonstrate how subtle alterations in performance history contain the critical potential of enlightenment orientalism.

Zara revolves around the fate of three Christian characters captured when Caesarea was sacked by Muslim armies. Two children, Zara and Nerestan, and a descendent of the Christian princes of Jerusalem named Lusignan, find themselves subject to Osman, the Sultan of Jerusalem, but they are all handled quite differently. Zara grows up in the seraglio fully accommodated to Muslim life; Nerestan is raised in a Muslim household but upon reaching adulthood is granted leave by the Sultan to go to France to raise the funds to ransom the other Christian slaves; and finally Lusignan, as an enemy combatant has been confined to the dungeons for much of his adult life where he has wallowed in despair for his dead wife and children. In a sense these differences amount to different modes of hospitality: Osman hosts Zara, Nerestan and Lusignan as future lover, potential rival and defeated enemy respectively. The play opens two years after Nerestan has been released and the action turns on his return to Jerusalem with the ransom money. His request for the release of the captives generates a crisis because over the course of her life the ostensibly orphaned Zara

9. See Fred L. Bergmann, 'Garrick's Zara,' PMLA, 74.3 (1959), 225-32 for a careful discussion of the production and adaptation history of the play.

10. The important exception here is Christine Gerrard's discussion of Hill's theatrical career in Aaron Hill: The Muses' Projector, 1685-1750 (Oxford: Oxford University Press, 2003), 172-85. 
has fallen in love with the Sultan. He too is in love with Zara and as their nuptials are pending he refuses to hand over Zara to Nerestan. Zara is relieved, but with the release of Lusignan a competing set of obligations are set into motion. Lusignan recognizes that Zara and Nerestan are his children, and thus Zara's obligations to Osman run counter to her familial and religious obligations to her father and brother. Lusignan and Nerestan force Zara to get baptized before her wedding, but Osman intercepts Nerestan's letter detailing the time and place for meeting with the priest and misinterprets it as an amorous assignation. In a fit of jealousy, Osman has Nerestan seized and stabs Zara. When he learns of his mistake he is overwhelmed by remorse and kills himself with the same dagger. ${ }^{11}$

Zara is basically caught between two triangles of affiliation; and the play, at least in Hill's 1736 rendering of Voltaire, is remarkable for the degree to which both 'families' or sets of relations are deemed comparable. At the head of the first triangle, Osman as host operates as both the surrogate parent and the future lover of Zara. His counterpart in the second triangle is Lusignan, Zara's biological parent and the impediment to her desire. Like Zara, Nerestan appears in both triangles: in the first triangle he too thrives with Osman as his surrogate father, and in the second, he finds himself deeply conflicted as Lusignan's long-lost son. This schematic comparison reveals two things: first, as host Osman is an effective parental surrogate for the missing Lusignan for much of Zara and Nerestan's lives; and second, the central conflicts in the plot emerge when figures shift from positions of familial care to those of potential sexual partners. When Osman shifts from the provider of hospitality to potential husband and when he misreads the brother Nerestan as the secret lover, the plot moves quickly to the elimination of these undecidable identities and to the death of the most troubling character of all-Zara. Zara is simultaneously captive, daughter, sister, friend, Christian, and Muslim,

11. In the play's prologue, Hill himself noted the similarity between the denouement of Voltaire's play and Othello. See Aaron Hill, 'Prologue,' Tragedy of Zara (London: Watts, 1736), 11-14. This is a reductive reading, but Osman was to suffer the same fate as Othello as the century progressed: in later performances the complexity of both characters was subsumed into increasingly stark representations of racial alterity, and thus the sense that their predicament was tragic became less and less recognizable. 
but when she is to be transformed into 'wife' all of these categories come into irresolvable conflict. She quite literally becomes the impossible accommodation of mutually distinct identities: identities that must remain separate for the other characters to retain their cultural and social position. Thus the tragedy's sacrifice of Zara clearly demarcates the cost of maintaining identity categories in a cosmopolitan world.

What is so remarkable about Voltaire's play and Hill's adaptation of it is the lengthy establishment of Osman's virtue in the first three acts. The Sultan's nobility, both as a ruler and as a future husband to Zara, is the subject of panegyric from the play's opening scene onward. At one level, this characterization of Osman in the early acts is crucial to the damning portrait of Christian intolerance in the fourth act and to the elaboration of the Sultan's jealousy in the final act. But it is also clear that Osman's virtue is fundamentally tied to his status as a just and benevolent host. This recasting of captivity as a scene of hospitality brings together the rules and customs of the household with the laws and practices of the state. In other words, hospitality is deployed as a feature of governmentality because of the shared figural relation to the home. This is crucial because Lusignan's account of the destruction of his home-by all reports the play's most moving scene, especially with Garrick in the role-establishes the moment where one regime of care, the family, is replaced by another, in this case the Sultanate of Jerusalem. The tight analogy between familial and political duty means that the play's most affecting moments of intrafamilial affiliation are put on the same continuum as the somewhat counter-intuitive assertion of obligation and desire of captive for captor, of subject for ruler.

There is much to be said about the specific mobilization of feeling in the tragedy, but the play itself and its capacity to explore the nobility of Osman and Zara's love was subject to quite violent transformations over its performance history. The description of the uncomfortable détente between two competing regimes of care is applicable to Hill's adaptation of Voltaire, but Garrick's adaptation of Hill, although at times an attempt to resuscitate elements of the French original downplayed in Hill's version, ruthlessly curtails Osman's claims to nobility. Although there is no published edition of Garrick's adaptation of Hill's Zara, there exists a detailed prompter's copy in Garrick's hand that 
likely dates to the late 1760 s. ${ }^{12}$ Close scrutiny reveals that Garrick's alterations to Hill's script consistently undermine the presentation of Osman's virtue in the early acts. ${ }^{13}$ This subtle, but violent, recasting of the play's moral economy yields a cascade of effects. First, the Sultan's regime of care is vitiated. Stripped of all greatness, the Sultan becomes an even more unsuitable match for Zara, whose desire now seems to arise out of something akin to Stockholm syndrome. This has the ancillary effect of making Lusignan's religious intolerance, above and beyond his parental concern, even more normative. Casting himself in this role, Garrick thus becomes the protector of virtue and Christian religion in the face of rapacious incursions from foreign powers. At this moment in the lead up to the Seven Years' War it is unclear how this would have been received, but one thing is certain: Garrick cancelled all internal parallels and links between the Sultan and the notion of monarchy. As noted above, Hill's play is replete with Osman's meditations on the thin line between kingship and tyranny. This is most movingly enacted by assertions of the substitutability of Osman and Lusignan-thus the degree to which the two characters structurally shadow one another is not incidental to the play's tragic meaning. It is at the very core of its argument. Without this potential interchangeability Zara's status as the figure that both consolidates and ruptures identity is lost and the play devolves into sentimentality. We should not be surprised to see Garrick, in the role of Lusignan, and later, Siddons in the role of Zara, re-orienting the play into a pathos-laden display of filial piety.

12. See Bergmann, 'Garrick's Zara', 227-29 for a discussion of this document and its likely date of production.

13. As Bergmann states, Garrick, keeping the types more distinct, prefers that Osman remain simply a heathen villain. He therefore eliminates such passages as the following, designed to stress Osman's tragic grandeur: 'I think, with Horror, on the dreadful Maxims,/Which harden Kings, insensibly, to Tyrants' (ii, 217-18); or this one, in which Osman reveals his greatness of soul in mourning the fate which has made Lusignan, last of the Christian kings of Jerusalem, his captive:

Such is the Law of States, had I been vanquish'd,

Thus had He said of Me:-I mourn his Lot,

Who must, in Fetters, lost to Day-light, pine,

And sigh away old Age, in Grief and Pain. (i, 247-50)

Nor is Osman allowed to say that he loves Lusignan 'for his virtue and his blood' (iii,19). In fact, Garrick cuts out the moralizing element which Voltaire, and Hill to an even greater degree, had scattered through Osman's speeches. Bergman, 'Garrick's Zara,' 230. 
But again this consolidation of Lusignan, Zara, and the celebrity of the players cast in these roles came at a very specific cost. By making Osman little more than a despotic villain, the tragedy loses both its political overtones and its primary scene of remorse. Osman's suicide, in Garrick's adaptation, seems aside from the point. But this may have been Garrick's objective all along. By containing monarchy in the character of Lusignan, the very notion of kingship comes under little scrutiny because, like the aged king, it is somewhat obsolete. In Hill's Zara we have two 'kings,' one who is captive to another and who has no claim to power. The Sultan, however, is very much alive and for that reason volatile. What would it mean to preserve this volatility in the 1750 s and 6os and beyond, when the limits of monarchical power were once again the focus increasingly fractious discussion both inside the realm and beyond into the broader imperium? Without any specific allegorization of politics, Garrick's stereotyping of Osman may be aimed at preventing the play from signifying too much in a time of political change. But we cannot avoid the recognition that this prophylactic gesture tilted the entire tragedy towards nostalgia-for a kind of decrepit kingship long since past, for forms of gender identity locked within the terms of she-tragedy and for versions of national identity remarkably separate from the increasingly global world within which these plays were performed.

With this account of Zara in mind, I would simply amplify Aravamudan's polemic against novelism by suggesting that our fixation on the domestic novel has distracted us from the incremental vitiation of the enlightenment critique of national and imperial state formations. As the century unfolds and Osman's virtue is slowly eroded, the complex scene of hospitality that Voltaire and Hill imagined becomes foreclosed and thus less available as a site for counter-memory. Any celebration of the novel's rise must be balanced against the attrition of enlightenment orientalism's capacity to check the vanity and selfpropelling motion of imperial fantasy. 


\section{IV - Mary Helen McMurran}

Western University

Srinivas Aravamudan's Enlightenment Orientalism makes significant contributions to the study of eighteenth-century fiction from a transnational perspective. The study includes expert readings of many overlooked Oriental fictions as well as fresh interpretations of the highlights of the genre. But quite apart from its virtuosic illumination of texts and contexts, it accomplishes a double liberation, first from Orientalism, and secondly, from the so-called rise of the novel - two narratives that have long determined our relationship with the undomestic fiction of the eighteenth century. In the introduction Aravamudan argues that Edward Said's model of will-to-power Orientalism does not apply to the kind of imaginative license and inchoate imperial strategy that characterized the early eighteenth century's Near East. Subsequent chapters, which collectively raise the Oriental tale from its subgeneric status, simultaneously discredit the story of the rise of the nationalrealist novel. It is no longer to be doubted that fictions themselves as well as the eighteenth century's own historical narrative of fiction were never strictly national in scope; the novel emerged from a translational legacy and, in particular, as a gift from the East. If the national-realist form won out, Aravamudan rightly argues, it was due to the disciplining of the aesthetic imagination and concerted public efforts to mythologize the novel's modern and national birth. Even powerful arguments for the isomorphosis between fictional and political forms, as in Said's famous reading of Mansfield Park's narrative authority as being in lock-step with national-imperial ideology, seem to dissolve in the face of the archive and arguments presented here.

Liberation is often understood as the act of being freed from something and indeed, Enlightenment Orientalism discharges us from two critical credos by exposing their implausibility. Perhaps we can turn the question around and also ask: What critical dispositions are we being freed toward? Oriental fiction is characterized throughout the book by fluidity, experimentation, and contingency rather than as a corpus or a foundation for the novel. For Aravamudan, the performance of fictionalizing is as important as the diegetic or fictional world created. Yet, this Orientalism does not simply sideline English realism 
to celebrate extravagance. Instead, the character of Orientalist fiction refreshingly readmits the Enlightenment's role as a partner in eighteenth-century novels, reincorporating idealism and moralism, as well as idea-driven narratives. For example, Gulliver's Travels no longer appears to be the outlier on the Defoe, Richardson, and Fielding chart of the novel's rise. Oriental tales are diverse vehicles for thinking differently through political structures, gender, religion, the cosmos, and human-animal relations. Defamiliarization is central and, not surprisingly, Oriental fiction foregrounds irony, parody, and paradox.

Aravamudan focuses on the cultural crossings of Oriental fiction more intently than on the restitution of Enlightenment to the fictional worlds of the eighteenth century. Whether in literary encounters produced by translations, or in pseudo-ethnography where the cultures are themselves fictional constructs, the notion of transculturation is at the forefront. Indeed, the word "transcultural" appears with great frequency, as do such terms as translational, cosmopolitan, global, and universal. While these terms counteract the stiffness of Said's orientalism, the notion's theoretical underpinnings receive little concentrated attention. For the most part, Aravamudan uses "transcultural" to designate the eighteenth-century discursive mode, which pretends to cultural exchange and is distinct from the large body of testimonybased discourse of intercultural relations in eighteenth-century texts and archives. One of the first appearances of "transcultural" is near the end of the introduction. Summing up the different sorts of Oriental fictions addressed in the following chapters, they are "modes sitting half way between the national and the transcultural, between the novel and the fable." (29) Standing for the representation or fictionalization of interactions between cultures, the transcultural can encompass an Orient fully masked behind a European projection with its light-footed semblance of fact. Conjoined to another concept as in the terms "transcultural reading" or "transcultural allegory," it seems to signify culture-crossing, once again distinguished from actual reports of exchanges. It implies, however, that aspects of Near Eastern and European culture are in transit, but what is moving is less clear, especially if the point is that these Orients are figments of a national or European imaginary.

In other places in Aravamudan's text, the conjunction of transcultural with another term is more capacious. For example, in the first 
chapter, he writes that the transmission of Arabian Nights from Arabic into French and English is a "global example of the transculturation between East and West that constituted Enlightenment Orientalism." (51) A few pages later, Arabian Nights is described as "translational and transcultural." (54) The result is also a "transculturation and transcreation." (56) It is not entirely clear here how the transcultural differs from translational, since linguistic renderings necessarily entail some kind of cultural negotiation. The translationality from Arabic to French and English is a particular and not unprecedented path of literary transit, but is claimed to be "global." In a subsequent passage, Clara Reeve's and Richard Hole's histories of fiction are "comparativist and transcultural," by which Aravamudan means to describe their inclusion of novels outside the English tradition, and they also "keep the flag flying for a cosmopolitan and indeed global conception of literature." (74) The transcultural, here allied with comparativism, cosmopolitanism and globality loses specificity, and we must wonder how each of these separate concepts signifies a different nuance of literary cross-fertilization. Finally, in his discussion of Montesquieu's Persian Letters, Aravamudan refers to its "transcultural universality," to indicate a universality of criticism and morality that moves away from cultural relativism without superseding it. $(82,91)$ In the previous examples, the conjunction of "transcultural" with other terms becomes pleonastic, but here, the transcultural and universal are oppositional notions synthesized into a single term. It is productive to ponder this tense symbiosis as the aspiration of the Persian Letters, though it is not entirely clear what theoretical work the transcultural performs on universality. When Aravamudan asks whether "culture is about contents associated with a political geography or a set of hypotheses that are themselves subject to dispute and transgression," the point is that within these fictions, culture is not positivist, and displaced by "negative propositions, satirical deflations, and philosophical and scientific juxtapositions." (200) If the conceptual purchase of culture cannot be sustained because it is often tantalizingly denaturalized by these fictions, what becomes of the transcultural as the study's model for Orientalized fiction?

I could not help but cheer on the arguments of Enlightenment Orientalism as they did away with the limitations imposed on eighteenthcentury fictions by national-realism and old Orientalism. If there is less 
substance to the transcultural than expected from a work that significantly revises Orientalism, this was not a disappointment, but rather a suggestion of the new critical disposition: one that emerges from the return of the Enlightenment to undomestic fiction. The passage about culture quoted above appears in the conclusion of Aravamudan's reading of Diderot's Les Bijoux indiscrets at a point where he reintroduces the role of Enlightenment. Aravamudan argues that Diderot's libertine tale, which deploys and dismantles cultural comparison in favor of negative propositions, satire, and queer juxtapositions, has been "given a name in retrospect: the Enlightenment." (200) The question of whether Enlightenment constitutes a culture is broached here only to be left behind as unapproachable. Yet taken within the study's larger literary-historical framework, this comments reveals that the transcultural, like the fleeting concept of culture, is not necessarily posed as a substantive concept to replace Orientalism. The transcultural may shed its rhetorical powers among other critical commonplaces and traditions to readmit Enlightenment. We may find reason to defend the Enlightenment's valorization of self-criticism even as it promoted the criticism of others, but this is the least of its possibilities. More importantly, this study begins to unearth the unrational and nonteleological set of engagements that suffuse the fictions of ideas about cosmogony and metempsychosis, as well as those about the state and sexuality. In overcoming our familiar critical narratives of Orientalism and the national novel, Aravamudan outlines a compelling path back to Enlightenment as it emerges with and against reason, order, and progress. Oriental fictions, among a crop of other fictions of ideas that have been under-serviced by novel criticism, fortuitously enable the recuperation of more complex configurations of Enlightenments. 


\section{V - SRinivas AraVAmUdAN \\ Duke University ${ }^{14}$}

More than a decade ago, Terry Castle asserted that, "the ball of eighteenth-century novel studies has been definitively kicked through the goal posts." 15 Yet, when Ros Ballaster published Fabulous Orients: Fictions of the East in England 1662-1785 in 2005, she legitimately claimed that there had been no book-length study of the oriental tale in English for almost a century. ${ }^{16}$ The lacuna could be explained, as the relationship between the oriental tale and the novel was eschewed in Castle's list of the problems solved once and for all; but it is the wager of books such as Ballaster's and mine that a reinvestigation of the various genres of eighteenth-century prose fiction moves the goal posts of novel studies to different territory.

The temporality of scholarship always forces new questions upon us as Katherine Binhammer presciently points out in her contribution. The questions before us today are not the same as those posed about the novel in the nineteenth century by Walter Scott, or even by Ian Watt in the twentieth. I have three brief reflections to justify moving the proverbial goal posts. These happen to be critical markers as well as etymological prefixes that respond collectively to the discussion and I go about this by using three pairs of post- and trans- concepts as rubrics.

\section{Postnovelism (transfiction)}

Novelism, as Clifford Siskin has named the overwhelming bias toward the genre as constitutive vehicle of modernity, has now receded with the emergence of powerful forms of narrative such as feature film,

14. Let me first express my sincere gratitude to the four other panelists, who have read Enlightenment Orientalism closely, finding matters therein to appreciate, as well as interrogate.

15. Terry Castle, unpublished paper presented at the University of Virginia 13 February 1999, cited in Lennard Davis, "Reconsidering Origins: How Novel Are Theories of the Novel?," Eighteenth-Century Fiction Vol. 12 nos. 2-3 (January-April 2000), 479-80.

16. Ros Ballaster, Fabulous Orients: Fictions of the East in England 1662-1785 (Oxford: Oxford University Press, 2005); and Martha Pike Conant, The Oriental Tale in England in the Eighteenth Century (New York: Columbia University Press, 19o8). 
interactive videogames, and other new media. Are we at a postnovelistic moment from where we can look back at the history of the novel, and much more broadly, at the history of fictional genres, with a new perspective? This was true of Ballaster's monograph's focus on "narrative moves," and the helpful pun of "transfictions that transfix us" as Gena Zuroski Jenkins suggests. We can look for counterhistories and sites of countermemory as Danny O'Quinn demonstrates, leveraging imputed loser genres against self-proclaimed winners, and reassessing forgotten receptions and ignored contextualizations.

Watt's teleology was by no means unproductive. It was a powerful theoretical machete that cleared a lot of the undergrowth, allowing for the erection of a spare English canon of Defoe, Richardson, and Fielding, capped by Austen, that has since been criticized for its androcentrism and progressivism. The Rise of the Novel had great cross-field appeal beyond the minor local skirmishes amongst period scholars. If Watt's contribution was a misreading, it was a powerful and a consequential one that brought a lot of positive attention to a field, and most important, energized new generations of scholars who built several storeys upon the platform he laid. It brought history and theory together powerfully, as Michael McKeon has argued, even as it overemphasized a British empiricist claim to the global trajectory of one national realist fiction writ large as universalist script. ${ }^{17}$ But in many respects Watt also had powerful theoretical predecessors from the Continental tradition who were staking their own claims about the novel as an engine of modernity: György Lukács, Ortega y Gasset, and Mikhail Bakhtin. To slightly loosen the Anglocentric grip on this metanarrative by switching from the effectivity of the novel to that of the oriental tale as a parallel engine of modernity, and devoting equal attention to French eighteenth century, as I have done, still leaves a bigger problem of Eurocentrism to confront, that I have only partially addressed. Structures once built cannot be dismantled entirely.

My overall aim was not to write a counterhistory of the novel, but to stage multiple interrogations of the realist paradigm via intergenres, with the oriental tale being my prime exhibit. Enlightenment

17. See Michael McKeon, "Watt's Rise of the Novel within the Tradition of the Rise of the Novel," Eighteenth-Century Fiction vol. 12 nos. 2-3 (January-April 2000), 253-76. 
Orientalism is an interruptive literary history that contests the exposition of British national realism and novelism with comparativist energies drawn from what is increasingly a postnovelistic moment. At the same time, just as much as Watt's groundclearing made short shrift of many writers, my emphasis veers away from national realism and toward non-novelistic prose genres promising transcultural access (more about that below). I have stayed close to the oriental tale as intergenre (albeit within broader prose fiction contexts), even as I have not strayed into a full-scale exploration of drama, lyric, music, painting, furniture, gardening, and popular culture.

I freely renounce any emergent partisanship toward the oriental tale (especially now that the book is written and has sallied forth into the world). As Fredric Jameson has recently argued, realism has always been contrasted with a host of opponents-epic, romance, idealism, modernism, oriental tale-and yet realism's tenacious continuation does make it a kind of straw man against which other genre-epistemologies can cut their teeth. ${ }^{18}$ My study of the oriental tale is itself a thought-experiment, akin to many of the oriental fictions that I analyze, a provisional exercise in a universe of dynamic cultural interaction, rather than a finished statement about a singular reality. We have many overlapping language games being played in genre history, many microhistories and generic protocols to follow up, and several openended ideological frameworks still awaiting disentanglement and reentanglement with newer epistemologies and genealogies.

\section{Postorientalism (transversality) ${ }^{19}$}

Having faced dismissal by partisans of national realism and avantgardists who used realist novels as the privileged vehicle for modernity narratives, the eighteenth-century oriental tale has suffered additional stigmatization since the powerful intervention made by Edward Said's Orientalism. Saidianism spurred retroactive applications of anti-orientalism as the ideological detoxification of genre history. Orientalism urges vigilance about the nexus between power and

18. Fredric Jameson, The Antinomies of Realism (New York: Verso, 2013), 4. Also cf. Binhammer's remarks above.

19. This is a controversial term, but I prefer this to Binhammer's more full-blown characterization of the "New Orientalisms" in eighteenth-century studies. 
knowledge; and yet, the mechanical application of its conclusions to periods and genres that antedate the high imperial era has been problematic. If to resist the rise of the novel was a particular way of swimming against the current, opposing the generalized political and cultural interpretations of representations of Europe's eastern flank is altogether another endeavor. The fusion of two apparent opposites, Enlightenment and Orientalism, appealed to me as a powerful heuristic, an apparent oxymoron actually revealed as a secret alliance, leading to eventual critical insight. While Watt did not talk explicitly about the Enlightenment, the modernity narrative he promulgated took it largely as given. Genres apparently retarded from the perspective of modernity have also been doubly dismissed (or relegated as suspect for containing negative stereotypes and inaccurate histories of "the Orient"). In this secondary rush to judgment, nineteenth-century conventions were yet again applied unconsciously to eighteenth-century artifacts that were found wanting.

The more I investigated the valence of these tales, the more I discovered that Orientalism, at least eighteenth-century Orientalism of a fictional nature, was a crucial part of the practice of Enlightenment disorientation (as Zuroski Jenkins has also suggested above). ${ }^{20}$ Eighteenthcentury oriental tales used "the Orient" as a moveable rather than fixed target to unsettle the binaries of "West" and "East," rather than reinforce them. The Fontenellian structure of a plurality of worlds was extant, and I build upon that framework to demonstrate the flexible nature of these "worlding" representations. These texts were recursive forms of pleasure (as O'Quinn asserts with respect to theatrical materials), flexible forms of apprehension during a time when knowledge was still scanty and aspirations concerning elsewhere were highly uneven, when there was still significant work to be done to undermine political despotism within Europe using indirect forms of representation.

Enlightenment and Orientalist fiction were allies, not adversaries. Oriental tales were indeed written in the eighteenth century alongside military and economic expansion and featured competition and vulnerability in relation to the Islamicate cultures of the Mediterranean. The full-fledged bureaucracies of modern empires developed decades

20. Ideology was first defined as a science of ideas and their origins by the Count Destutt de Tracy in the decade after the French Revolution. 
later, fixing these ventures into solidified definitions of specific areas, peoples, and cultures. For this reason, it might be worth considering the eighteenth-century oriental tale as "pre-" or "pan-ideological," deployed by writers of varied political and intellectual persuasions. As Binhammer suggests above, rather than treat space as territory, these tales are "about a utopic universal in which space is transversal."

In a recent study published at the same time, Humberto Garcia excavates a space for Islam as a radical supplement to the long eighteenth century rather than letting it play the usual role of a religious archaism that Europe leaves behind in the quest for its singular and secular modernity. Garcia's objective, of seeking to undo the binary oppositions between a progressive Enlightenment history of European literature and the Manichaean history of Asia as backward in relation to the narrative of progress, matches my own. ${ }^{21}$ If Enlightenment Orientalism does it by putting aside progressive accounts of the novel in favor of a reappropriation of the oriental tale, Garcia goes about it by critiquing arguments that use the teleology of Romanticism as a secularized replacement of Christian religious discourse. Said followed the lead of M. H. Abrams' Natural Supernaturalism in this regard and applied that model to Islamicate culture as a victim, rather than also as hidden supplement and aspirational model. Postorientalist vantage points allow us to see that Orientalism is neither static nor univocal, nor even always easily decoded in political terms. As Zuroski Jenkins argues, new theories of reading, once articulated, help us define a new theory of subjectivity in relation to a transversal cosmopolitan space. I had already followed this track of the continuation of Orientalism by its objects in another study, arguing that self-orientalization allows a peculiar form of diasporic agency in colonial and postcolonial South Asian religious discourses. ${ }^{22}$

\section{Postmodernism (transculturation)}

Our current vantage point allows modernist as well as postmodernist methodological avenues for newer interpretation. Watt's take on real-

21. Humberto Garcia, Islam and the English Enlightenment, 1670-1840 (Baltimore and London: Johns Hopkins University Press, 2012).

22. Srinivas Aravamudan, Guru English: South Asian Religion in a Cosmopolitan Language (Princeton and London: Princeton University Press, 2006). 
ism was more modernist than realist, insofar as it took "formal realism" to be an aesthetic and epistemological vehicle instead of asserting the formlessness of immediate reality and the unvarnished truth-claims of individual testimony as the genre-bending novel-writers of the eighteenth century proclaimed.

In this context, the pleonasm of transculturation as it is used in my study (and as very efficiently identified by Mary Helen McMurran) is something to be explained. Indeed, the transcultural is rarely delivered as contents in these tales, that are better at delivering the "third space" of experimental innovation, more than the "second space" of the putative Orient, with the "first" space being that of national realism that the oriental tale rejects. Here the self-conscious critique might be a reiteration of the symptom rather than a realist alternative to it. In an earlier study, Tropicopolitans, I characterized one of the great Orientalist texts of the eighteenth century, Mary Wortley Montagu's Turkish Embassy Letters, as a form of levantinization. Montagu, who attempts to pass over into Ottoman high culture, ultimately returns with her experience as a literary commodity. Using Victor Turner's anthropological application of William Van Gennep's important understandings of transculturation, we can discern that an experience of liminality (perhaps the Holy Grail of genuine content-oriented transculturation) is reconverted into what Turner calls the liminoid, virtual transculturation rather than transculturation tout court. ${ }^{23}$ Hence, in relation to these tales, the transcultural "loses specificity", as McMurran points out. The oriental tale is ultimately a liminoid intergenre, and whatever transculturation it offers is a hybrid cosmopolitan vehicle anchored in a refusal of the first space of Europe and oriented toward a third space yet to be articulated. To that degree, Orientalist representations of this fictional type are in danger of subsequently "standing in" as ersatz for the second space, even though that space was initially available more as fantasy than reality. Of course, such tales can be seen as eliding a genuine anthropology, and thwarting "real access" to the other, whoever that may be, but that failure should not devalue the importance of these fictions. If anything, the standard move from these textual

23. For a fuller discussion of levantinization and the liminoid in relation to Mary Wortley Montagu, see Srinivas Aravamudan, Tropicopolitans: Colonialism and Agency, 1688-1804 (Durham, NC: Duke University Press, 1999), 159-89, 169-70. 
representations - to actual histories of the areas they represent-poses the greater danger of misrecognition, and involves the tedium of constantly correcting earlier distortion, an activity that keeps Saidianism of the mechanical type very busy.

The postmodernism of vantage point recognizes the difficulty of mimetic access both in the first space as well as in the third. To the degree we identify "the postmodern" as available vicariously avant la lettre in the metafictions of the eighteenth century, we undo the neat periodizations that blunt the performative effect of fictions on readers. Reading these texts in their original contexts alerts today's readers to the disorientations they were already capable of performing. These texts were powerful fantasies generating alternative realities, interrogating their times satirically, and opening themselves up toward partly determined futures.

Literary history can never lose its temporal situation, and cannot shake itself free of Nachträglichkeit, the retroactive agency of deferred action. Postmodernism does not free us of the Enlightenment, but makes multiple temporalities collide, even as we are drawn back within the Enlightenment complex. The reading subject is psychoanalytically regrounded, neither achieving pure identification with the past, nor breaking entirely free of it. In this way, the eighteenth century, read as an anticipation of the postmodern is transcultural, but liminoid. The vacuity of liminoid experience connects with the weak power of literature rather than the direct appeal of politics, making available to us a gestural aesthetics that is subtle and indirect. This typifies the transcultural universal of Enlightenment Orientalism. 